\title{
THE PROTECTION OF KARST AQUIFERS: THE EXAMPLE OF THE BISTRICA KARST SPRING (SW SLOVENIA)
}

\author{
VAROVANJE KRAŠKIH VODONOSNIKOV: PRIMER \\ KRAŠKEGA IZVIRA BISTRICE (JZ SLOVENIJA)
}

GREGOR KOVAČIČ ${ }^{1}$

${ }^{1}$ University of Primorska, Faculty of humanities Koper, Department of geography, Glagoljaška 8, SI-6000 KOPER, SLOVENIJA, e-mail: gregor.kovacic@fhs-kp.si

Prejeto / received: 10. 6. 2003 


\begin{abstract}
UDC: 551.44:556.3(497-14)

Gregor Kovačič: The Protection of Karst Aquifers: the Example of the Bistrica Karst Spring (SW Slovenia)
\end{abstract}

Karst springs are important drinking water sources both in Slovenia and elsewhere in the world. Due to their specific structure, karst aquifers are in most cases highly vulnerable to pollution. Through the example of the Bistrica karst spring, the author highlights the problems of karst groundwater protection and presents the main shortcomings and weaknesses of the relevant legislation in force and of established practices in the field of the protection of karst aquifers in Slovenia. Despite relatively favourable conditions for water protection (scarce population, less intensive agricultural activities etc.) as compared with karst areas elsewhere in the world, many important karst springs in Slovenia are improperly protected. Water protection regimes are often established inappropriately and control over the implementation of protective measures is inefficient. Key words: Karst hydrology, Sne•nik plateau, water protection zone, Waters Act.

Izvleček

UDK: 551.44:556.3(497-14)

\title{
Gregor Kovačič: Varovanje kraških vodonosnikov: primer kraškega izvira Bistrice (JZ Slovenija)
}

Kraški izviri predstavljajo pomemben vir pitne vode tako v Sloveniji kot v svetu. Zaradi specifične zgradbe so kraški vodonosniki v večini zelo občutljivi na onesna•enje. Avtor na primeru kraškega izvira Bistrica izpostavi problematiko varovanja kraške podtalnice ter predstavi glavne pomanjkljivosti ter slabosti sedanje zakonodaje in uveljavljene prakse na področju varovanja kraških vodonosnikov v Sloveniji. Kljub relativno ugodnim razmeram za varovanje (redka poseljenost, manj intenzivno kmetijstvo,...) v primerjavi s kraškimi območji drugod po svetu je veliko pomembnih kraških izvirov slabo zavarovanih. Vodovarstveni re•imi so največkrat slabo definirani, nadzor nad izvajanjem zaščitnih ukrepov pa neučinkovit.

Ključne besede: Kraška hidrologija, Sne•niška planota, vodovarstvena cona, Zakon o vodah. 


\section{INTRODUCTION}

Over wide areas, especially in karst regions, groundwater from karst aquifers forms the only available drinking water resource. About one quarter of the global population is supplied by karst waters (Goldscheider 2002), while in some European Alpine countries karst water contributes up to $50 \%$ of the total drinking water supply and $43 \%$ in the case of Slovenia (Brečko Grubar \& Plut 2001).

Karst aquifers are characterized by low self-cleaning capacity (natural remediation and neutralizing) and are particularly vulnerable to pollution. Each karst system is unique and has its individual characteristics. The structure of karst aquifers is highly heterogeneous and anisotropic. It can be considered as a network of conduits of high permeability surrounded by a large volume of low permeability rock, where seepage water percolates only through the net of tiny solutional widened fractures and bedding planes. Karst groundwater is recharged by both diffuse infiltration and concentrated point recharge via sinking streams and dolines. The layers above the groundwater surface (topsoil, subsoil, non-karstic bedrock) provide some protection, but due to their frequent absence a fair amount of the recharge and consequently contaminants infiltrate directly into the karst network, where they are transported rapidly through karstic conduits over large distances towards karst springs or wells without effective attenuation of contaminant concentration (Hötzl 1996). Due to high flow velocities and consequently a short residence time there is only short time available for efficient emergency action in the event of pollution. On the other hand, some types of contamination can be more easily remedied due to a shorter residence time, however taking into account the fact that each karst system is unique and responds to a specific contaminant in a different way (Doerfliger et al. 1999; COST action 65 1995). Since the attenuation of contaminants does not work effectively in karst aquifers, careful land-use planning is essential.

Protection zones delineated in the catchment areas of karst springs and wells result in land-use restrictions and conflicts, regardless of the fact that karst areas, especially high karst plateaus, are usually sparsely populated. Different regulations on the protection of karst groundwater resources have been adopted to avoid overexploitation and prevent pollution, but they are often inadequate and usually not supervised. The example of the Bistrica karst spring illustrates some problems of water management in the area of the uninhabited Sne•nik plateau (NW Dinarids), where sufficient protection zones have not yet been set up and water protection regulations have not been implemented properly.

\section{KARST GROUNDWATER PROTECTION WITHIN THE SLOVENE LEGISLATIVE FRAMEWORK}

In all European countries groundwater is considered as a finite, natural resource of great value and should be managed and protected on a sustainable basis. The European Water Framework Directive (2000) establishes a strategic framework for Community action in the field of water policy. The Directive demands sustainable water use based on the long-term protection of water resources, progressively reducing the existing pollution of groundwater and preventing its further pollution. The Directive aims primarily at protecting resources, i.e. the total groundwater body, whereas the current practice refers mostly to sources, i.e. the captured springs or wells (Hötzl 2002). The idea of groundwater vulnerability assessment is indirectly included in the Directive and the initial characterization of all groundwater bodies and the extent to which they are at risk is 
obligatory (Goldscheider 2002; Directive 2000/60/EC). Accordingly, these requirements also apply to naturally extremely sensitive and vulnerable karst aquifers.

Basic legislative provisions concerning groundwater protection policy in Slovenia and consequently the protection of karst aquifers are part of the new Waters Act, proclaimed in July 2002. Pursuant to Articles 74 to 76 of the Act, the government and its institutions are responsible to establish water protection areas and regimes and to ensure the implementation of the provisions in each protection zone (Waters Act 2002). Since the new Waters Act has been in force only for a relatively short period, no regulation acts have yet been adopted to standardize the methodology and rules for defining the water protection zones of groundwater resources intended for human consumption.

According to the old Waters Act of 1981 and its amendments adopted during the following decades, the delineation of water protection zones fell within the responsibility of local communities, which, however, led to confusion. Different approaches and methodologies for the determination of water protection areas consequently resulted in non-comparable water protection areas and regimes for different water resources or sources. This is rather problematic for land-use planning and land management decisions, such as the building of motorways across regionally heterogeneous areas with different water protection zones (Prestor 2002).

In the last years, three different methodologies for the determination of water protection zones have been in use in Slovenia (Breznik 1976; Rismal 1993; Petauer \& Veselič 1997). A common characteristic of all three approaches is the transfer time of a contaminant from the point of injection to the target (a spring or a pumping well), which defines different water protection zones. All three methodologies include the division of the hydrological background of drinking water resources into at least three basic protection zones. However, they differ markedly in their method for determining the extent of individual protection zones (Prestor 2002). This situation in the field of groundwater resources protection in Slovenia is unfavourable for several reasons. A common problem of determining different protection zones is related to knowledge about the hydrogeological characteristics of a specific aquifer, especially in heterogeneous karst areas. Groundwater protection zones in Slovene karst regions are often not established on a solid hydrogeological basis. Consequently, differences in approaches between different methodologies are usually less important for the determination of water protection areas in karst than those arising from the assessment of the natural sensitivity and vulnerability of karst aquifers using one and the same methodology but based on different knowledge about the hydrogeological conditions of catchment areas (Prestor 2002). In most cases, protection zones delineated in the background of karst springs are based only on available information on the geological structure, though sufficient tracer tests, whereby underground flow velocities are measured, are needed for the adequate validation of already established water protection zones. Due to the special characteristics of Slovene karst regions and the absence of sufficient data, the important parameters for intrinsic vulnerability assessment of karst aquifers, such as the function of the protective cover and karst network development, are generally not taken into consideration. This means that such protection zones are often insufficient and may be ineffective as a result. Since the protection of drinking water resources was in the past the responsibility of local communities, as provided by the old Waters Act (1981), adequate protection was hindered by administrative borders between these communities. The Ri•ana karst springs, which are tapped for the water supply of the Slovene coastal region, are an excellent example. Most of the second water protection zones of the 
abovementioned springs are situated on the territory of the neighbouring municipalities and hence not protected. According to the new Waters Act (2002) such and similar cases will be regulated through instructions issued by the government. Unregulated conditions in the field of water protection management in Slovenia and increasing conflicts between land use and demands for karst groundwater protection of, especially among different neighbouring communities, often lead to a situation where there are no water protection areas and regulations established. It must be stressed that even in cases where water protection zones and regimes are established the implementation of regulations is frequently not effective. There is practically no control over potential and actual polluters of karst groundwater. Thus many important karst springs tapped for water supply are still not protected in Slovenia.

\section{THE STUDY AREA: THE BISTRICA KARST SPRING}

\section{Introduction}

In spite of its relatively low discharge, the Bistrica karst spring (Fig. 1) is one of the most important drinking water resources in southwestern Slovenia. The spring is tapped for the water supply of the major part of the Municipality of Ilirska Bistrica, a few villages in the neighbouring Municipality of Hrpelje - Kozina and a part of the territory of the Republic of Croatia in the hinterland of the Gulf of Quarnero. In total, about 15,000 people are supplied from this spring. The significance of the spring is increased by the fact that there is no other drinking water resource available which can be used in the event of contamination. The spring is a permanent source of the hydrogeological unit of several karst springs of the river Bistrica situated along the western margin of the Sne•nik karst plateau at the contact with impermeable flysch of the Reka valley in the vicinity of the town of Ilirska Bistrica.

\section{Hydrological characteristics of the spring and its background}

The hydrogeological background of the spring stretches over the high karst of the Sne•nik plateau. Deeply karstified Cretaceous and Jurassic limestones, dolomites and dolomite-limestone breccias of good and medium permeability prevail (Šikić et al. 1972; Šikić \& Pleničar 1975). The detailed geological structure of the background is shown in Fig. 3. Tectonically, the Sne•nik plateau is part of the Sne•nik thrust sheet and belongs to the northwestern Dinarids (Placer 1981). The central part of the plateau lies at an average elevation of 1,000 to 1,400 m; the highest peak is Sne•nik $(1796 \mathrm{~m})$. The plateau karst surface is characterised by conical-shaped hills, deep dolines of various shapes, size and morphogenesis, deep shafts and typical glacio-karstic depressions filled with glacial debris from the last Glacial when the mountain of Sne•nik was ice-capped and some small slope glaciers were active (Šifrer 1959). In addition to running towards the Bistrica karst springs, the autochthonous precipitation water which percolates into the deep karst aquifer of the Sne nik plateau runs towards other karst springs in its margin. The underground watershed between several karst springs and also between the Adriatic and Black Sea basins is found in the area of the plateau. Although the local erosion base of the Reka valley, which drains karst springs in the western margin of the plateau, is among the lowest $(400 \mathrm{~m})$, the majority of abundant precipitation runs towards the catchment area of the rivers Ljubljanica $(555 \mathrm{~m})$ and Riječina (350 $\mathrm{m})$. The latter is captured for the water supply of the city of Rijeka and the neighbouring settlements 
in the hinterland of the Gulf of Quarnero, Croatia (Kovačič 2003).

The Bistrica karst springs constitute a system of several periodical and permanent karst sources situated at an altitude of 420 to $470 \mathrm{~m}$ at the contact of Cretaceous limestones and Eocene flysch. During the dry period they have a discharge of only about $140 \mathrm{l} / \mathrm{s}$ at the gauging station. However, after a long period of heavy rains they achieve a discharge of more than $30 \mathrm{~m}^{3} / \mathrm{s}$. Water tapped for supply reduces the volume of the total discharge at the gauging station by approximately $100 \mathrm{l} / \mathrm{s}$, regardless of the season. Of all karst springs in the area the Bistrica karst spring is the most abundant. During the dry period this spring has a discharge of only $200 \mathrm{l} / \mathrm{s}$ and is exploited to the maximum, but it never dries out. Owing to this, it has been captured for water supply since the beginning of the $20^{\text {th }}$ century. The outflow capacity of the spring is limited, which increases the discharge of the periodical and higher situated springs after heavy rains (Fig. 2). The time distribution of the mean monthly discharges at the Ilirska Bistrica gauging station and of the mean monthly precipitation at the Ilirska Bistrica precipitation station is shown in Fig. 4. The first maximum corresponds to the largest quantity of precipitation in the catchment area in November. The second maximum in April is the result of snow melting in spring, but the figures hardly exceed the average. The lowest mean discharges occur in July and August and the second minimum in February. Higher discharges are typical for the colder part of the year (HMZ 1999; Kovačič 2003).

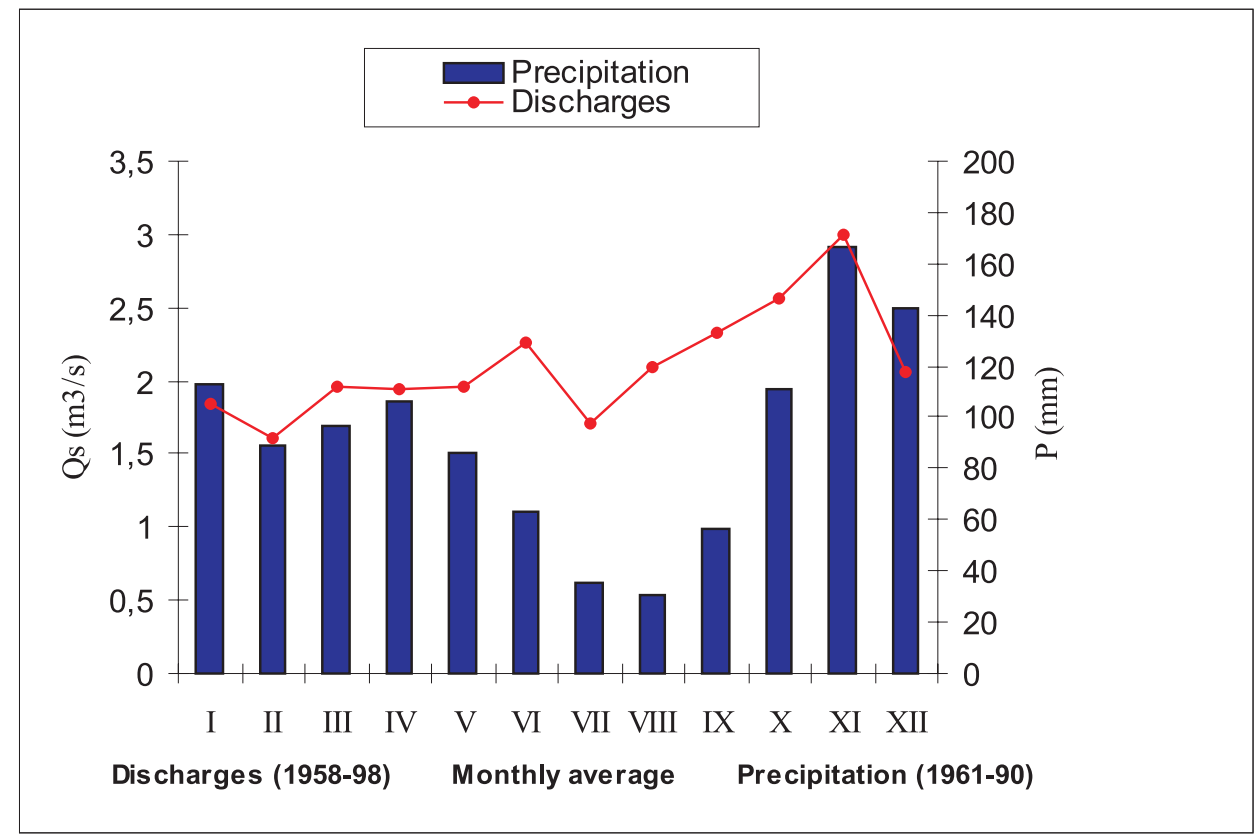

Fig. 4: The Bistrica monthly mean discharges (period 1958-98) at the gauging station Ilirska Bistrica and monthly mean precipitation (period 1961-90) at the precipitation station Ilirska Bistrica (HMZ 1999; Zupančič 1995).

Sl. 4: Povprečni mesečni pretoki Bistrice v obdobju med 1958-98 na vodomerni postaji Ilirska Bistrica in povprečne mesečne padavine v obdobju 1961-90 na padavinski postaji Ilirska Bistrica (HMZ 1999; Zupančič 1995). 
The estimated mean annual discharge of the karst springs is about $1.85 \mathrm{~m}^{3} / \mathrm{s}$ (Kovačič 2003). The annual amount of precipitation at the Ilirska Bistrica precipitation station, situated approximately $1 \mathrm{~km}$ to the north of the Bistrica karst spring, is in total $1569 \mathrm{~mm}$ (Kolbezen \& Pristov 1998). Due to an orographic barrier, precipitation in the central parts of the Sne•nik plateau is rather abundant and the peaks of the mountains reach approximately $3000 \mathrm{~mm}$ (Gomance $2738 \mathrm{~mm}$, Mašun $2041 \mathrm{~mm}$ ) (Zupančič 1995). According to the simplified equation of water balance, from which it can be assumed that the changes in water reserves in an average year are negligible, and given the interpolated values of the mean annual precipitation $(1800 \mathrm{~mm})$ and evapotranspiration $(620 \mathrm{~mm})$ in the background, it can be assessed that the size of the catchment area of the springs is approximately $50 \mathrm{~km}^{2}$. It must be stressed that this number is only an estimate based on calculations made by Kolobezen \& Pristov (1998), which means that further hydrological investigations for more accurate assessment of the extent and the boundaries of the catchment area are needed.

\section{Intrinsic vulnerability and the definition of protection zones}

The concept of the intrinsic vulnerability assessment of karst groundwater is based on the assumption that the physical environment provides some natural protection to groundwater against human impacts, and therefore takes into account the geological, hydrological and hydrogeological characteristics of an area in question (COST Action 620 2002). The natural sensitivity of karst aquifers to pollution is rather high. The protective function of the different layers between the land surface (the point of release of contaminants) and the groundwater is of great importance for the intrinsic attenuation capacity of aquifers. There are considerable differences among the various types of karst environment and in many cases the function of the protective cover is rather insignificant because of soil and subsoil deficiency and the presence of a well-developed zone of epikarst where flow concentration, as a dominant process, increases the intrinsic vulnerability of the karst system.

Since the catchment area of the Bistrica karst spring has not been studied in detail until now, the aim of this section is not to present a complete intrinsic vulnerability assessment based on accurate data on underground flow velocities, the depth of specific overlaying layers, the development of the karstic network etc., but rather to reveal some basic geomorphological and geological characteristics of the Sne•nik plateau which indirectly indicate the characteristics of the upper layers of the aquifer and consequently its self-cleaning capacity and susceptibility to pollution. The intensive karstification of the catchment area is evidenced by the systems of various dolines and ouvalas, of which some are more than $150 \mathrm{~m}$ deep. The traces of glaciation are preserved in the highest parts of the plateau (Šifrer 1959). On higher elevations the dolines and ouvalas are filled with periglacial and glacial debris and on some spots small moraines can be found as well. These locations are less sensitive to pollution as intergranular porosity offers some protection for the karst aquifer. Some fluvio-glacial geomorphological features, probably originating from the cool periods of the Pleistocene, are preserved on some locations within the catchment area, such as small longitudinal valley-like depressions with dolines filled with well sorted, finegrained carbonate rubble and erosion channels on steep slopes, but there is no surface runoff at the present time. Intensive karstification and poor soil cover on the limestones enable the precipitation water to drain underground quickly by concentrated recharge via dolines, shafts and vast karrenfields, which are better expressed in fractured and broken fault zones. Consequently, 
the protective cover of the overlaying layers is completely bypassed and such locations are naturally more sensitive and particularly exposed to pollution. On several locations runnels and karren on bare rocky relief appear. Generally, the intrinsic vulnerability of the Bistrica karst spring catchment area is relatively high due to the absence of overlying layers on the one hand and the presence of well-developed fracture and broken fault zones expressed by karrenfields, systems of deep dolines and shafts, on the other. In order to establish more adequate source or resource intrinsic vulnerability maps, detailed mapping and further investigations regarding karst network development, especially tracer tests of the area, are needed.

The concept of intrinsic vulnerability assessment was, to some extent, used for the delineation of the protection zones by Petauer et al. in 2002, as elaborated in the expert groundwork documentation for the protection of the Bistrica karst spring. The intrinsic vulnerability maps contained in the abovementioned documentation distinguish between five different categories of intrinsic vulnerability regarding karst areas within the catchment area of the Bistrica karst spring. These categories are mostly based on the hydrogeological characteristics of different karst rock types. The concept includes source intrinsic vulnerability mapping instead of resource mapping. Therefore the transfer time of a possible contaminant from the point of release to the source (potential intervention time) is the most important factor for the determination of different source intrinsic vulnerability categories and consequently different water protection zones. The function of the protective cover, however, is not taken into consideration, except in cases of noticeable differences in the geological structure. For example, areas covered with thicker layers of alluvial and glaciofluvial deposits are considered less vulnerable than the rest of the catchment area.

According to Petauer et al. (2002) the water protection zones of the Bistrica karst spring extend over approximately $90 \mathrm{~km}^{2}$. Due to insufficient knowledge about the hydrogeological characteristics of the plateau, the margin of the catchment area of the spring in question has been set far inside the eastern part of the Sne•nik plateau, where there are obvious geological modifications in the fault zone. Although the extent of the protection zones is slightly overestimated, it is rational in terms of water protection with the aim of preventing any inconsiderate human activities in the environment which could affect the quality of groundwater. It must be stressed that the delineation of water protection zones has been carried out on the basis of general hydrogeological data, such as the mean annual discharge of the spring, the geological structure of the catchment area and the basic geomorphologic features typical of different stages of the development of the karst surface. The water protection zones of the source have not been validated through tracer tests.

\section{Description of hazards and source protection}

Due to its geological, geomorphological and consequently climate conditions the Sne•nik karst plateau is most inconvenient for agriculture and for this reason uninhabited. The plateau is densely wooded with mixed fir/beech forests; on higher elevations and in deep karst dolines spruce trees appear also. In the deepest karst dolines belts of dwarf pines and mountainous meadows without trees can be found. The former are typical on the slopes of the mountain Sne•nik and some other summits in its vicinity. Sustainable forest management has a tradition of several hundred years and the traditional industry in the vicinity of the plateau is based on wood exploitation. On lower elevations the former vast pastures are becoming increasingly overgrown with pine forests. Today, only a few of them are still used, mostly for sheep pasturing. In terms of karst water 


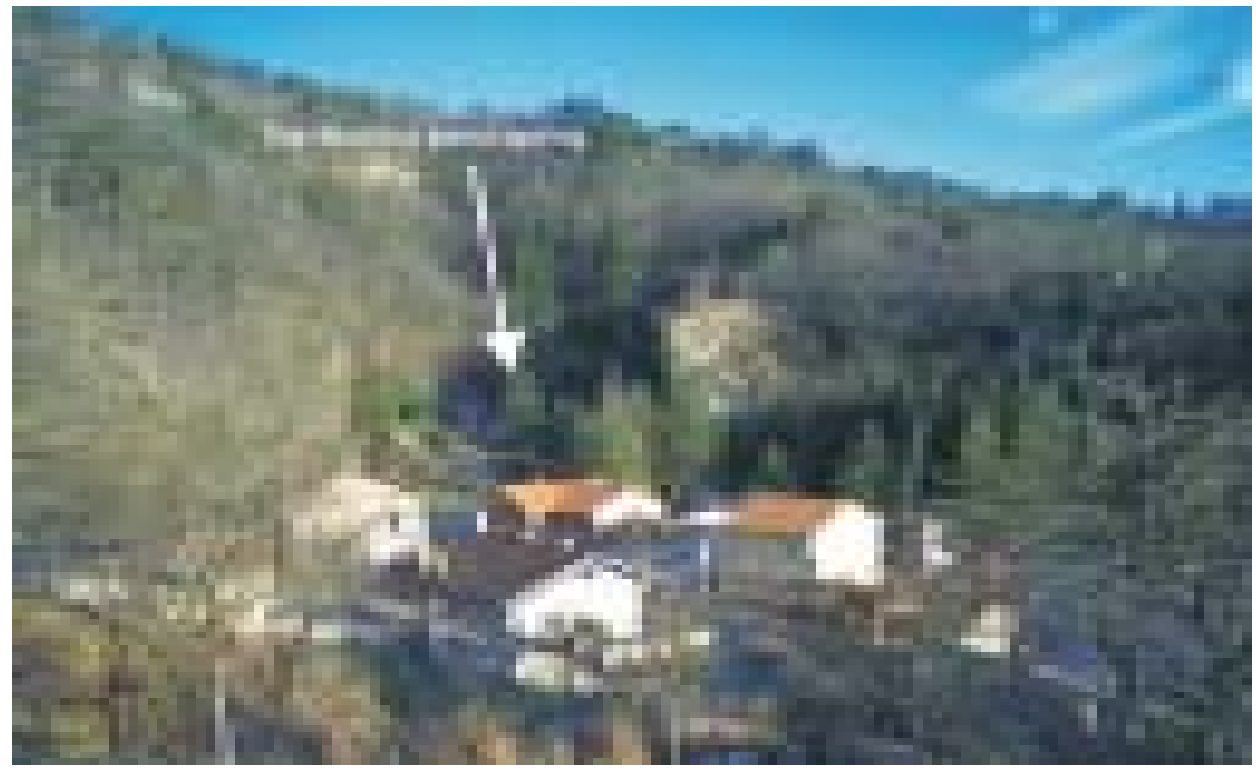

Fig. 1: Pocket valley of the Bistrica karst spring (Photo: G. Kovačič). Sl. 1: Zatrepna dolina kraškega izvira Bistrica (Foto: G. Kovačič).

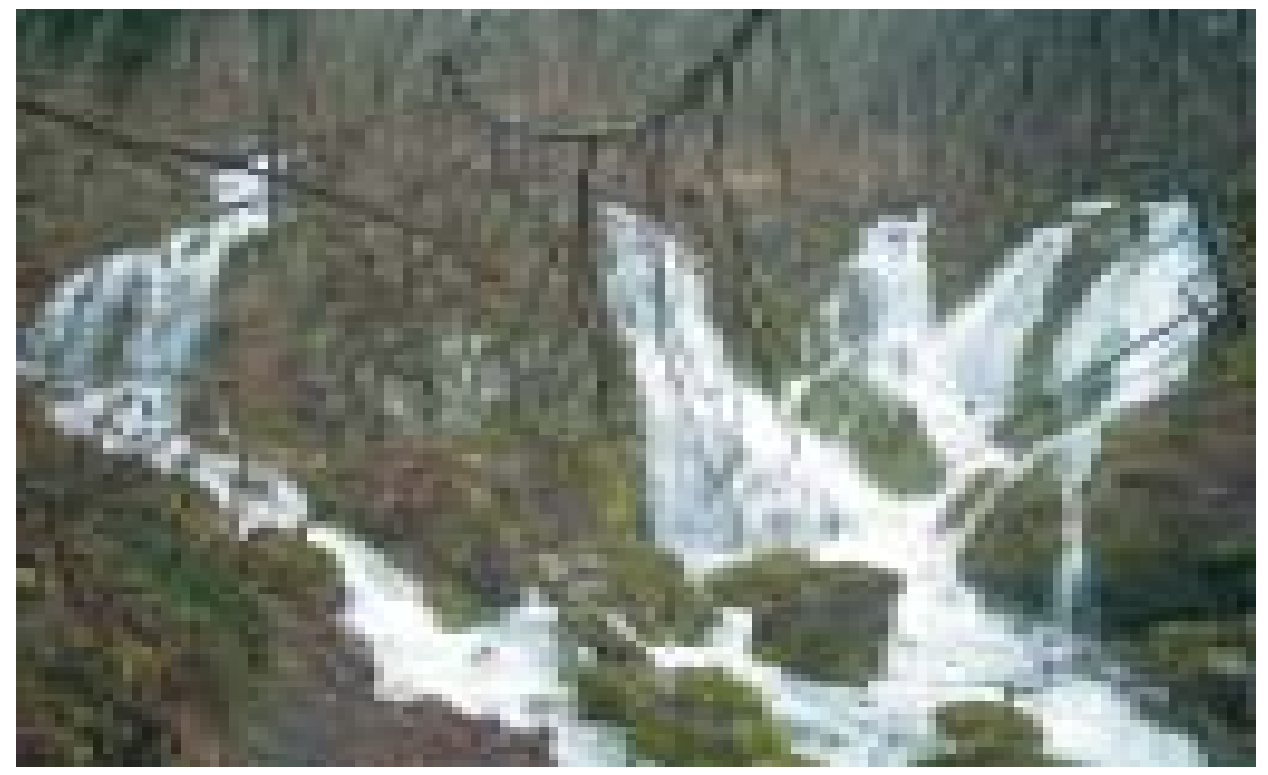

Fig. 2: Sušec karst spring (at high discharge) is a periodical spring of the Bistrica karst springs system (Photo: G. Kovačič).

Sl. 2: Kraški izvir Sušec (ob visoki vodi) je občasen izvir v sistemu kraških izvirov Bistrice (Foto: G. Kovačič). 
protection such low agriculture activity is relatively favourable, however a number of other examples can be given to illustrate the conflicts of interest between other human activities taking place in the catchment area and the protection of karst water tapped for water supply. The locations of hazards are shown in Fig. 3.

A trapshooting ground situated only $700 \mathrm{~m}$ from the spring is the most serious hazard for drinking water (Fig. 5). Estimates show that the concentration of lead (the element with which cartridges used for trapshooting are filled) in the soil is rather high. According to the Decree on the input of dangerous substances and plant nutritients into the soil of 1996, as few as 150 bullets fired would be enough to reach the annual maximum permissible quantities of lead entered into the soil on an active shooting ground. However, in the case of this trapshooting ground this number is far exceeded each year. While percolating through the thin layer of soil, the infiltrating precipitation water becomes, to some extent, contaminated with lead, which is a result of weak acids. The earlier physical-chemical examinations of the spring water showed a concentration of lead which was still within the maximum permissible values. According to analyses carried out later, however, a slight increase in the values of lead is recorded and the trend is not encouraging. In June 2002 the concentration of lead at the capture reached the value of $4 \mu \mathrm{g} / \mathrm{l}$ (the maximum permissible value for drinkalble water is $10 \mu \mathrm{g} / \mathrm{l}$ ) (Kovačič 2003). It is impossible to determine the total quantity of lead in the soil cover. No analyses of the soil have been carried out so far in

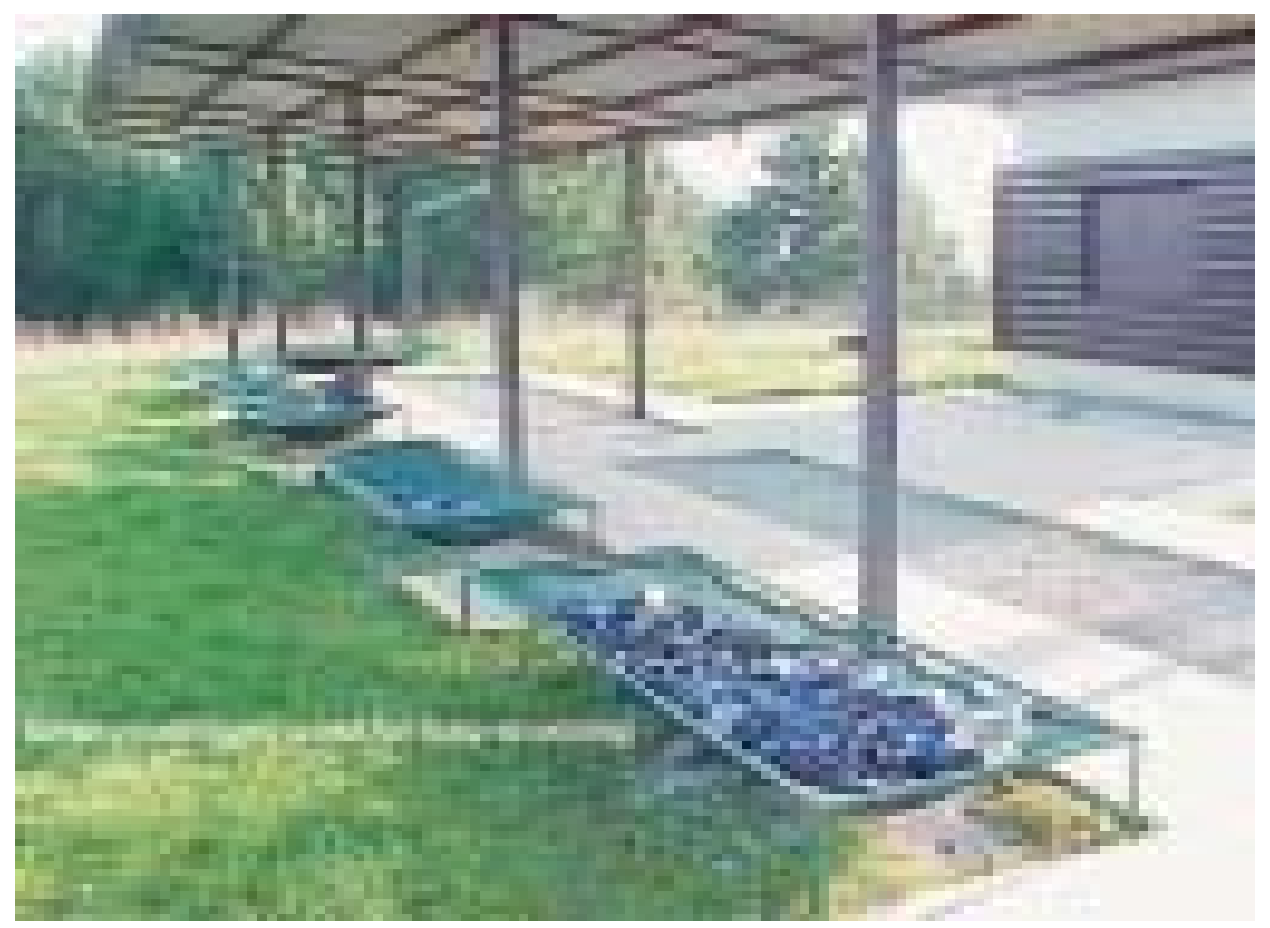

Fig. 5: Trapshooting ground in the background of the Bistrica spring (Photo: G. Kovačič). Sl. 5: Trap-športno strelišče v zaledju izvira Bistrica (Foto: G. Kovačič). 


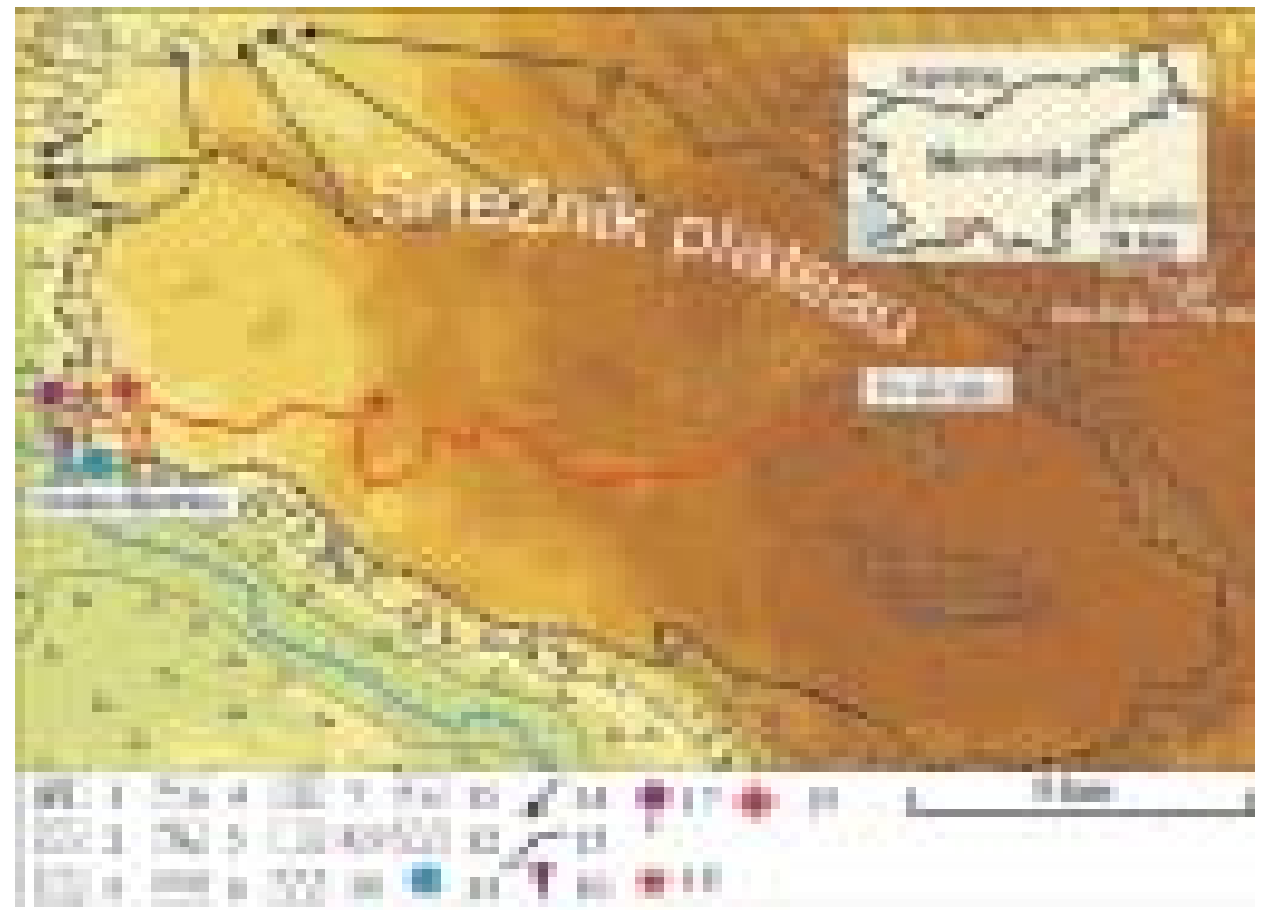

Fig. 3: Geological map of the Bistrica karst spring background and its potential pollutants (after Sikic et al. 1972; Petauer et al. 2002; Kovačič 2003)

Legend: Slope rubble (Holocene), 2. Alluvial sediments (Holocene), 3. Glaciofluvial deposits (Pleistocene), 4. Flysch rocks: shales, marlstones, sandstones, calcarenites, breccias and conglomerates, 5. Light grey and grey limestones, grey brown and black limestones and marly limestones (Peleogene), 6. Light grey and white crystalline limestones (Upper Cretaceous), 7. Exchanging of light coloured limestones and dolomites (Upper Cretaceous), 8. Light coloured limestones (Upper and Lower Cretaceous), 9. Dolomite-limestone breccia (Upper and Lower Cretaceous), 10. Limestone and dolomite (Lower Cretaceous), 11. Light grey and dark grey limestone (Upper Jurassic), 12. Light grey and dark grey limestone (Upper Jurassic) 13. Bistrica karst spring, 14. Suppositional underground water flow towards the other karst springs, 15. Suggested water-protecting area of the Bistrica karst spring, 16. Gauging station Ilirska Bistrica,17. Precipitation station Ilirska Bistrica, 18. Quarry, 19. Trapshooting ground.

Sl. 3: Geološka zgradba hidrografskega zaledja kraškega izvira Bistrica in njegovi potencialni onesna•evalci (prirejeno po: Sikić et al, 1972; Petauer et al. 2002; Kovačič, 2003)

Legenda: 1. Pobočni grušč (holocen), 2. Aluvialni nanosi (holocen), 3. Glaciofluvialni sedimenti (pleistocen), 4. Flišni sedimenti: menjavanje glinovcev, laporovcev, peščenjaka, kalkarenitov, breč in konglomeratov (eocen), 5. Svetlosivi in sivi ter sivorjavi do črni apnenci do lapornati apnenci (paleogen), 6. Svetlosivi in beli prekristalizirani apnenci (zg. kreda), 7. Menjavanje plasti svetlih apnencev in dolomitov (zg. kreda), 8. Svetli apnenci (sp. in zg. kreda), 9. Dolomitno apnena breča (sp. in zg. kreda), 10. Apnenec in dolomit (sp. kreda) 11. Svetlosiv apnenec (zg jura), 12. Svetlosiv in temnosiv apnenec (zg. jura), 13. Kraški izvir Bistrica, 14. Domnevni podzemeljski dotok vode $v$ druge kraške izvire, 15. Predlagana meja vodovarstvenega območja kraškega izvira Bistrica, 16. Vodomerna postaja Ilirska Bistrica, 17. Padavinska postaja Ilirska Bistrica, 18. Kamnolom, 19. Trap-športno strelišče. 
order to study the behaviour of lead as a specific contaminant and to examine the intrinsic processes of the soil for its possible physical attenuation. The closure of the trapshooting ground and the remediation of the contaminated surface and the soil cover are necessary to ensure quality drinking water also in the future.

The exploitation of limestone quarries is also a possible source of pollution. Although the lower quarry, located only $200 \mathrm{~m}$ from the capture, is no longer in operation, it is still used for inappropriate oil storage and several other unsuitable activities which increase the potential risk of pollution. Chemical analyses of the water captured from the spring show sporadically increased values of mineral oils, which are likely to result from inappropriate limestone exploitation in the past which did not meet water protection standards. In June 2002 the quantity of mineral oils in the spring water reached the maximum permissible value for drinkable water, which is 10 ěg/l (Kovačič 2003). The remediation of the lower quarry is therefore essential for a long-term protection of drinking water. Activities carried out in the still operating upper limestone quarry should also comply with water protection standards.

Located in the area of the Sne•nik plateau is Sviščaki, a tourist resort with a restaurant and some 90 weekend houses. Although it is situated in the central part of the plateau, it should be considered a potential source of pollution because the eastern boundary of the catchment area has not yet been precisely delineated. In addition, the inadequate sewerage infrastructure represents a possible threat to underground water quality.

Apart from pollution from construction, sports, tourism and forestry activities the Bistrica karst spring is also endangered by traffic. The local road connecting Ilirska Bistrica with Sviščaki runs right above the capture and is not built according to water protection standards. The influence of traffic on the quality of the spring water is negligible, however in the case of an accident the contaminants would reach the spring very quickly, making efficient emergency action impossible.

The microbiological quality of the spring is satisfactory and generally meets drinking water quality standards even without previous treatment at the drinking water treatment plant situated right after the capture site (Kovačič 2003). Similarly, as in the case of other karst springs, an increase in microbial content can be observed after heavy rains following a longer dry period.

In accordance with the Waters Act of 1981, in 1985 the Municipality of Ilirska Bistrica has enacted an Ordinance on the delineation of water protection zones and the adoption of measures for the protection of drinking water resources. Pursuant to the Ordinance, individual water protection zones with their respective regimes have been established on the basis of surface distances from the source in the direction of the underground flow. Since no adequate hydrogeological investigations of the Bistrica spring aquifer have been carried out, the length and width of specific protection zones are based on an arbitrarily determined underground flow direction. In a highly heterogeneous and anisotropic karst environment with evident concentration of flow via points of fast infiltration, water protection zones delineated in this way are groundless and useless. Nevertheless, this Ordinance is the only legal instrument in force regarding the protection of drinking water in the Municipality of Ilirska Bistrica and thus also the protection of the background of the Bistrica karst spring. In comparison with newer methodologies used for the determination of water protection zones, the measures provided for by the Ordinance are inappropriate and too mild. However, no water protection measures have been carried out so far. Expert groundwork regarding the protection of the Bistrica karst spring was carried out by Juren \& Krivic in 1989. 
However, due to conflicts of interests no decree based on this groundwork has been passed. In 2002 a new proposal for the protection of all drinking water resources in the Municipality of Ilirska Bistrica was presented by Petauer et al. However, in line with the new Waters Act of 2002 the proposal was not accepted by the local government. One of the most important drinking water resources in SW Slovenia thus remains practically unprotected.

\section{CONCLUSION}

Groundwater protection is gaining more and more importance in karst areas throughout the world as well as in Europe. Karst aquifers are often involved in water and land-use planning conflicts because of their high natural sensibility to pollution. Fundamental legislative provisions concerning groundwater protection policy in Europe are laid down in the European Water Framework Directive (2000). The Directive is obligatory for all European countries, including Slovenia, whose Waters Act of 2002 is based on it.

In Slovenia, karst groundwater is often considered as an abundant high-quality drinking water resource despite the fact that it is extremely vulnerable to pollution. Its protection in land-use management is often neglected and is not seen as an important issue although the first signs of contamination have already been recorded and some karst springs initially intended for water supply are now inappropriate for human consumption. Obvious offenders of water protection measures are usually not prosecuted because of inefficient inspection. The wide areas of karst regions in Slovenia are either uninhabited or scarcely populated with almost no agricultural activities or only with traditional ones. High karst plateaus recharge most of the important karst springs. Increasing population pressures on the karst areas of Slovenia demand careful land-use planning from decision makers, with special regard to the protection of quality drinking water resources. The catchment areas of particular karst springs are often very large and watersheds are often difficult to determine and are also variable in time, dependent on the respective hydrogeological conditions. In practice, it is impossible to demand maximum protection for entire karst aquifers as the resulting land-use restrictions would not be acceptable in most cases, though some methodologies for groundwater protection are aimed at protecting the entire water body. According to such logic, almost $43 \%$ of the Slovene territory would be protected, which is, however, not appropriate. It is essential to protect at least those areas which are particularly vulnerable to pollution, however further investigations and studies are needed to provide more adequate information on the hydrogeological characteristics of karst aquifers. Based on such information karst water source or resource vulnerability maps can be established and used as a practical and applicable tool for land-use planning and protection zoning.

The example of the Bistrica karst spring, presented in this paper, shows that even in uninhabited karst areas some serious potential polluters can be found which constitute a threat to the quality of drinking water. Compared with more densely populated and industrialized karst regions around Europe with more intensive agricultural activities, such uninhabited areas are more appropriate for water protection. Nevertheless, they are still not protected because of the conflicts of interests between land-use and water protection, though it would not take much effort to provide sufficient protection of karst water. 


\section{ACKNOWLEDGMENTS}

- to Metka Petrič for her constructive comments.

- $\quad$ to Primo• Kovačič for language editing.

- to Jure Hajna for his help with cartography.

\section{REFERENCES}

Brečko Grubar, V. \& D. Plut, 2001: Kakovost virov pitne vode v Sloveniji. - Ujma, 14-15, 238244, Ljubljana.

Breznik, M., 1976: Metodologija zaščite podzemne pitne vode ter določitve varstvenih območij in pasov. Regionalni prostorski plan RS 3/4. Zasnove uporabe prostora. Vodno gospodarstvo Ljubljana, Zavod SRS za dru•beno planiranje, $176 \mathrm{p}$.

COST action 65, 1995: Hydrogeological aspects of groundwater protection in karstic areas. Final report. - European Commission, Report EUR 16574 EN, Directorat-General: Science, Research and Development, 446 p., Brüssel, Luxemburg.

COST action 620, 2002: Final Report of Working Group 1 (Intrinsic Vulnerability)- $2^{\text {nd }}$ Draft. Compiled by Nico Goldscheider, 76 p., (unpublished).

Decree on the input of dangerous substances and plant nutritients into the soil. 1996: Official Gazette of the Republic of Slovenia, 68, 5769-5737.

Doerfliger, N., Jeannin, P.Y. \& F. Zwahlen, 1999: Water vulnerability assessment in karst environments: a new method of defining protection areas using a multi-attribute approach and GIS tools (EPIK method). - Environmental Geology, 39 (2), 165-176.

EUROPEAN WATER FRAMEWORK DIRECTIVE, 2000: Directive 2000/60/EC of the European Parliament and the Council of 23 October 2000 establishing a framework for Community action in the field of water policy. - Official Journal of the European Communities, L 327, $72 \mathrm{p}$.

Goldscheider, N., 2002: Hydrogeology and vulnerability of karst systems - examples from the Northern Alps and Swabian Alb. - PhD Thesis. University of Karlsruhe, Faculty for Bioand Geoscience, 236 p., Karlsruhe.

Hidrometeorološki zavod RS, 1999: MOP, Agencija RS za okolje, interni podatki.

Hötzl, H., 1996: Grundwassershutz in Karstgebieten. - Grundwasser, 1, 5-11, Hannover.

Hötzl, H., 2002: Groundwater Protection and the European Water Framework Directive. - Pangeo Austria - Earth sciences in Austria, Österreichische Geologische Gesellschaft \& Institut für Geologie und Paläontologie, Universität Salzburg, 77-79, Salzburg.

Juren, A. \& P. Krivic 1989: Strokovne podlage za zavarovanje vodnih virov in vodnih zalog kot osnova za sprejem odloka za zaščito vodnega vira Bistrice (Ilirska Bistrica). Geološki zavod Ljubljana, TOZD geologija, geotehnika in geofizika, 8 p., Ljubljana.

Kolbezen, M. \& J. Pristov, 1998: Površinski vodotoki in vodna bilanca Slovenije.- MOPHidrometeorološki zavod Republike Slovenije, 98 p., Ljubljana.

Kovačič, G., 2003: Kraški izviri Bistrice (JZ Slovenija). - Annales, Series historia naturalis, Koper (in press).

Odlok o določitvi varstvenih pasov in ukrepov za zavarovanje vodnih virov, občina Ilirska Bistrica. 1985: Uradne objave. Primorske novice. 39, 29, 5.4.1985, 118-119.

Petauer, D. \& Juren, A. \& Štucin, P. \& S. Ilovar, 2002: Strokovne podlage za zaščito vodnih virov 
občine Ilirska Bistrica. - GEOOKO \& GeoSi, 66 p., Ljubljana.

Petauer, D. \& Veselič, M., 1997: Metodologija določevanja zaščitenih območij podzemnih voda. Ministrstvo za okolje in prostor, 13 p., Ljubljana

Placer, L., 1981: Geološka zgradba jugozahodne Slovenije. - Geologija, 24/1, 27-60, Ljubljana.

Prestor, J., 2002: Problematika določanja varstvenih pasov in razporeditve ukrepov za zaščito vodnih virov. - Zbornik seminarjev Varstvo in kvaliteta pitne vode, Inštitut za sanitarno in•enirstvo, 69-77.

Rismal, M., 1993: Zaščita podtalnice - Strokovno navodilo za izdelavo normativnih aktov za zavarovanje kakovosti podtalnice. FAGG, Ljubljana.

Šifrer, M., 1959: Obseg pleistocenske poledenitve na Notranjskem Sne•niku.- Geografski zbornik, 5, 27-83, Ljubljana.

Šikić, D. \& Pleničar, M. \& M. Šparica, 1972: Osnovna geološka karta SFRJ 1:100.000, list Ilirska Bistrica. - Zvezni geološki zavod Beograd, Beograd.

Šikić, D. \& M. Pleničar, 1975: Osnovna geološka karta Jugoslavije. Tolmač za list Ilirska Bistrica. - Zvezni geološki zavod Beograd, 51 p., Beograd.

Waters act. 1981: Official Gazette of the Republic of Slovenia, 38, 2308-2320.

Waters act. 2002: Official Gazette of the Republic of Slovenia, 67, 7648-7680.

Zupančič, B., 1995: Klimatogeografija Slovenije, Padavine 1961-1990. - MOP- Hidrometeorološki zavod Republike Slovenije, 366 p., Ljubljana.

\section{VAROVANJE KRAŠKIH VODONOSNIKOV: PRIMER KRAŠKEGA IZVIRA BISTRICE (JZ SLOVENIJA)}

\section{Povzetek}

V številnih območjih sveta, podzemna voda iz kraških vodonosnikov predstavlja edini vir pitne vode. Dele• oskrbe s pitno vodo iz kraških izvirov in vrtin v nekaterih alpskih dr•avah dosega $50 \%$, v primeru Slovenije pa znaša $43 \%$. Zaradi nizkih samočistilnih sposobnosti so kraški vodonosniki izjemno občutljivi na onesna•enje. Hidrografska zaledja posameznih kraških izvirov so zelo obse•na, zato je smiselno varovati predvsem tista območja, ki so najbolj občutljiva na onesna•enje zaradi človeških dejavnosti.

Področje varovanja kakovosti in zalog podzemne vode v Evropi določa Direktiva 2000/60/ES Evropskega parlamenta in sveta. Osnovno zakonodajo s področja varovanja kraške podtalnice v Sloveniji določa Zakon o vodah, sprejet leta 2002. Zakon predpisuje, da vodovarstvene pasove in re•im varovanja posameznih virov pitne vode določi vlada, vendar podzakonski akti, ki bi urejali omenjeno področje še niso sprejeti. Varovanje virov pitne vode je bilo glede na prejšnji Zakon o vodah iz leta $1981 \mathrm{v}$ rokah lokalnih skupnosti, kar se še danes odra•a v neurejenih razmerah na področju varovanja kraške podtalnice. Kljub izredni občutljivosti na onesna•evanje se kraški izviri v Sloveniji največkrat smatrajo kot neomejen kakovosten vir pitne vode, zato je njihovo varovanje pri načrtovanju človekovih aktivnosti v zaledju večkrat spregledano. Glavni vzroki neprimerne 
zaščite zaenkrat še kakovostne pitne vode iz kraških vodonosnikov v Sloveniji so nezadostno poznavanje hidrogeoloških značilnosti kraških vodonosnikov, neurejene zakonske razmere na področju varovanja pitne vode, navzkri•je interesov med posameznimi uporabniki prostora, neizvajanje varstvenega re•ima in neučinkovit nadzor nad potencialnimi in dejanskimi onesna•evalci ter odsotnost primerne metodologije določanja kart občutljivosti in ranljivosti kraških vodonosnikov, ki so dobra podlaga za izdelavo ustreznih vodovarstvenih območij in primerno varovanje kraških voda tudi v prihodnosti.

Primer kraškega izvira Bistrica ka•e, da lahko naletimo na resne potencialne onesna $\bullet$ evalce kraške vode tudi na neposeljenih visokih kraških planotah. Te so $\mathrm{v}$ primerjavi z bolj gosto naseljenimi kraškimi območji drugod po Evropi izjemno ugodna območja z vidika varovanja pitne vode. Kraški izvir Bistrica je stalen izvir v sistemu kraških izvirov Bistrice in je zajet za oskrbo s pitno vodo. Hidrografsko zaledje izvira označuje globoki kras Sne•niške planote z dobro propustnostjo, zgrajen prete•no v apnencih, dolomitih ter apnenčasto dolomitnih brečah kredne in jurske starosti (Sl. 3). Napajalno zaledje izvira je relativno dobro omejeno samo s kraškim robom na zahodnem delu planote, medtem ko je meja proti vzhodnemu robu Sne•niške planote nejasna. Pokrajinska občutljivost napajalnega zaledja kraškega izvira Bistrica je z izjemo nekaj manjših območij pokritih s fluvioglacialnim materialom, relativno visoka. Odsotnost zaščitnih pokrovov in navzočnost dobro razvitih razpoklinskih in porušenih prelomnih con, izra•enih s polji globokih škrapelj, sistemi globokih vrtač, kotličev in brezen, omogočata hitro odtekanje padavinske vode v notranjost, kar zmanjšuje mo•nost •e tako omejenega naravnega čiščenja. Kraški izvir Bistrica je ogro•en zaradi športne, gradbeniške, turistične in gozdarske dejavnosti ter z njimi povezanega

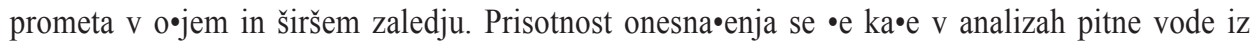
zajetja, kot sta denimo povečana vsebnost svinca in občasno povečanje prisotnosti mineralnih olj, vendar so vse vrednosti znotraj dovoljenih mejnih količin. Kraški izvir Bistrica je zavarovan s z občinskim odlokom, ki ni izdelan na podlagi hidrogeoloških raziskav zaledja. Re•im varovanja je preblago definiran in se ne izvaja. Strokovne podlage za sprejetje odloka o zavarovanju omenjenega izvira so bile izdelane $\bullet$ e dvakrat, vendar odlok do danes še ni bil sprejet, z novo zakonodajo pa je pristojnost varovanja virov pitne vode prešla v roke dr•ave. Tako ostaja eden izmed pomembnejših kraških izvirov JZ Slovenije praktično nezavarovan. 